\title{
Influence of Organic and Inorganic Mulches on Yield and its Attributes of Khasi Mandarin (Citrus reticulata Blanco) in Foothill Region of Nagaland
}

\author{
Alongba Jamir*, Manoj Dutta and Sentirenla Jamir \\ Department of Soil \& Water conservation, Nagaland University, SASRD, \\ Medziphema, Nagaland, India \\ *Corresponding author
}

\section{Keywords}

Khasi Mandarin, Mulching, Yield, Fruit weight, Fruit quality

\section{Article Info}

Accepted:

15 September 2020 Available Online: 10 October 2020

\section{A B S T R A C T}

A field experiment was carried out in 15-years old Khasi Mandarin trees growing in the farmer's field in mid-hill regions of Mokokchung District of Nagaland during the year 2016-18. Completely Randomized Design (CRD) with three number of replications was employed for nine treatments using organic mulches viz., $5 \mathrm{~cm}$ thick layer of rice husk, saw dust, chopped banana leaves and pseudo-stem, FYM, forest leaves \& rice straw above the soil surface around the tree trunk up to a distance of one metre radius and inorganic mulches viz., black polythene and transparent mulch of $100 \mu$. The analysis on the effect of mulching on yield revealed that mulching with black polythene $\left(\mathrm{M}_{8}\right)$ resulted in maximum yield in both the experimental years i.e., 31.18 and $32.12 \mathrm{~kg} /$ tree respectively and the subsequent highest yield was obtained from the transparent polythene mulch $\left(\mathrm{M}_{7}\right)$ with 30.80 and $31.40 \mathrm{~kg} /$ tree and the lowest was recorded under control $\left(\mathrm{M}_{0}\right)$ with 25.10 and $25.85 \mathrm{~kg} /$ tree in both the years respectively. The yield attributes showed that the maximum fruit size was recorded in black polythene mulch $\left(\mathrm{M}_{8}\right)$ measuring 48.60 and $49.04 \mathrm{~cm}^{2}$ both the years of observation, the minimum fruit size was recorded under no mulch condition $\left(\mathrm{M}_{0}\right)$ with a mean value of $40.08 \mathrm{~cm}^{2}$. The data pertaining to the weight of fruit indicated that the weight was highest under black polythene mulch $\left(\mathrm{M}_{8}\right)$ with 125.57 and $128.57 \mathrm{~g}$ during 2016 and 2017 respectively, subsequently followed by transparent polythene $\left(\mathrm{M}_{7}\right)$. The treatment devoid of mulched materials $\left(\mathrm{M}_{0}\right)$ recorded the lowest fruit weight mean value of $109.26 \mathrm{~g}$. The quality attributes analysis recorded differences amongst the various treatments tested with TSS values ranging $10.89-11.53{ }^{\circ}$ Brix, acidity ranging $0.24-0.44 \%$ and reducing sugar ranging $6.73-8.21 \%$, amongst which black polythene $\left(\mathrm{M}_{8}\right)$ mulch gave the best result and the minimum quality parameters were recorded under control $\left(\mathrm{M}_{0}\right)$. Firmness of harvested fruits borne under different mulched treatments recorded the firmest (2.13) under rice husk mulch $\left(\mathrm{M}_{1}\right)$ followed by no mulch $\left(\mathrm{M}_{0}\right)$, in both the years of investigation.

\section{Introduction}

Khasi mandarin is one of the premiere citrus cultivar that has gained a commercial stature in North-East India. It has a good shelf life and is labelled as the "King of Oranges". Khasi Mandarin alone occupies nearly 41.52 $\%$ of the total area and $40.51 \%$ of the total 
citrus fruits produced under citrus cultivation in India (Horticulture statistics at a glance, 2018). The quality production of citrus fruits is highly dependent on the soil moisture availability. The presence of adequate moisture in the soil is vital for growth and physiological processes. Citrus (Citrus spp.) tree is an evergreen tree and consequently the sap circulation never entirely ceases and transpiration take place throughout the year and thus require good amount of water compared to the other subtropical fruits. In North-East the months of November to March, however, are deprived of rainfall thus producing a dry period. Due to lack of knowledge and economic resources for proper water conservation approaches and no established irrigation means in these regions, the conservation of soil moisture in the root zone of the tree canopy by application of mulches becomes an economic alternative technique. Mulching is an agricultural technology in which the soil is roofed with organic and inorganic materials. Mulching plays an important role in conservation of soil moisture during dry periods, as well as improves physical, biological and chemical properties of soil. The systematic study on the effect of mulching on soil moisture conservation and performance of citrus under Nagaland condition has not been carried out. The crop is mainly dependent on rainfed cultivation in the region and therefore keeping in view and taking all these into consideration the present investigation was carried out to find ways and means to increase the yield and reduce the cost of production so that there is enough fruit production to meet the requirement of the consumers.

\section{Materials and Methods}

The mulching experiment was carried out on 15-years old Khasi Mandarin trees which were selected and treated with different mulches for fruit collection at Chuchuyimlang
Village under Mokokchung district of Nagaland. The experiment consisted of nine (9) treatments in Completely Randomized Design (CRD) with three replications. The treatments were $\mathrm{M}_{0^{-}}$No mulch, $\mathrm{M}_{1^{-}}$Rice husk, $\mathrm{M}_{2}$ - Saw dust, $\mathrm{M}_{3}$ - Chopped banana leaves \& pseudo stem, $\mathrm{M}_{4}-\mathrm{FYM}, \mathrm{M}_{5}$ - Forest leaves, $\quad \mathbf{M}_{6}$-Rice straw, $\mathbf{M}_{7}$-Transparent polythene $(100 \mu), \quad \mathrm{M}_{8}$-Black polythene $(100 \mu)$. For organic treatments, $5 \mathrm{~cm}$ layer of rice husk, saw dust, chopped banana leaves and pseudo-stem, FYM, forest leaves \& rice straw were applied above the soil surface around the tree trunk up to a distance of one metre radius, respectively. The Recommended dose of fertilizer (RDF) for the investigation was $900 \mathrm{~g} \mathrm{~N}, 700 \mathrm{~g}_{2} \mathrm{O}_{5}$, $600 \mathrm{~g} \mathrm{~K}_{2} \mathrm{O}$ per plant. The citrus trees were maintained pest and disease free throughout the experiment. Standard procedures were followed for the estimation of yield attributing and fruit quality parameters. The yield was calculated as the product of average fruit weight and the number of fruits per plant. The average length of the fruit was measured from the distal end to the apical tip of the fruit and the breadth was measured at the wider portion of the fruit with the help of Vernier Caliper and the result was expressed in centimetre $(\mathrm{cm})$. The weight of the fruit was measured with the help of electronic weighing balance and results expressed in grams $(\mathrm{g})$.

Different quality analysis method was done after juice extraction. The Total soluble solids (TSS) content of the juice was determined with the help of ERMA Hand Refractometer, calibrated at $20^{\circ} \mathrm{C}$ temperature, and the results were represented as ${ }^{\circ} \mathrm{Brix}$. The standard method (AOAC, 2002) was followed to determine the titratable acidity of fruit juice and reducing sugar of fruits was estimated by titrating the juice against Fehling $\mathrm{A}$ and Fehling B reagents using Methylene blue as an indicator following the method of Lane 
and Enyon (Ranganna, 2008). Parameter of firmness of the fruits was estimated using a five level Hedonic Scale developed by Amarine et al., (1965). The data of the different observations were analysed statistically following the methods described by Gomez and Gomez (1984). Fisher Snedecor ' $F$ ' test was used to determine the significance and non-significance of the variance due to different treatments at $5 \%$ level of significance.

\section{Results and Discussion}

\section{Effect of mulching on fruit yield/ tree (kg)}

The experimental results relating to fruit yield per tree revealed that the plants treated with various mulching materials resulted in better fruit yield compared to control. Mulching with black polythene $\left(\mathrm{M}_{8}\right)$ resulted in maximum yield in both the experimental years with 31.18 and $32.12 \mathrm{~kg}$ respectively with mean of $31.65 \mathrm{~kg} / \mathrm{plant}$ and the subsequent highest was obtained from the transparent polythene mulch $\left(\mathrm{M}_{7}\right)$ with 30.80 and $31.40 \mathrm{~kg}$ during the study period. Among the treatments studied, the lowest fruit yield per tree was recorded under control $\left(\mathrm{M}_{0}\right)$ with 25.10 and $25.85 \mathrm{~kg} / \mathrm{plant}$ in both the years respectively. These finding of higher yield under polythene mulch may be attributed to higher number of flowers and increased fruit set due to increased available water in the root zone of the crop, with less evaporation losses and better weed control. It may also be attributed to comparatively increased soil temperature, proper moisture availability (as influenced by mulches), elevated $\mathrm{CO}_{2}$ level and respiration rate, proper root growth, better uptake of nutrients, and absence of weeds in the field which were responsible for creating favourable microclimate around plants, resulting in efficient utilization of photosynthates for better growth, photosynthate substrates mobilization and development of the plants. Polythene mulch is known to cause chimney effect which results in abundant $\mathrm{CO}_{2}$ availability for plants which is necessary for photosynthesis leading to added higher plant growth since plastic mulch is nearly impervious to $\mathrm{CO}_{2}$. Polythene mulch is also responsible for reduced fertilizer leaching, higher uptake of nutrients, increased water use efficiency, which improved the plant performance and ultimately vegetative growth. The results are in line with the findings of Mal et al., (2006) who reported that more number of flowers recorded in plants under black polythene mulch in pomegranate cv. Ganesh. Bakshi et al., (2014) also reported highest number of fruits per plant in black polythene mulch in strawberry cv. Chandler. The present findings are also in agreement with the verdicts of Kher et al., (2010) in strawberry cv. Chandler, Gosh and Bauri (2003) in Mango cv. Himsagar, Shirgure et al., (2003) in Nagpur mandarin, Patra et al., (2004) in Guava cv. Sardar and Castaneda et al., (2009) on strawberry, Sharma and Kathiravan (2009) in Plum cv. Santa Rosa. In contrast, this result differed from the study Kumar et al., (2012) while studying the impact of different mulching materials on growth, yield and quality of strawberry reported significantly higher fruit yield under transparent polyethylene mulch followed by black polyethylene mulch while it was minimum in control.

\section{Effect of mulching on fruit size $\left(\mathrm{cm}^{2}\right)$}

The results obtained on fruit size as depicted in the table 1 revealed that there was significant difference among the treatments. The maximum fruit size was recorded in black polythene mulch $\left(\mathrm{M}_{8}\right)$ measuring 48.60 and $49.04 \mathrm{~cm}^{2}$ followed by the treatment with transparent polythene $\left(\mathrm{M}_{7}\right)$ that recorded 46.82 and $47.12 \mathrm{~cm}^{2}$ in both the years of observation with a mean value of 48.82 and $46.97 \mathrm{~cm}^{2}$ respectively. The minimum fruit 
size was recorded under no mulch $\left(\mathrm{M}_{0}\right)$ condition with 39.89 and $40.27 \mathrm{~cm}^{2}$ during 2016 and 2017 respectively with a mean value of $40.08 \mathrm{~cm}^{2}$. The various mulches created a micro-climate condition catering to consistent available soil moisture in the plant basin due to which the roots remained probably active throughout the irrigation season thus leading to optimum nutrient availability, uptake and proper translocation of food materials which accelerated the fruit growth and development.

The results are in agreement with Bakshi et al., (2014) who recorded maximum fruit length of $3.93 \mathrm{~cm}$ and fruit breadth of $3.16 \mathrm{~cm}$ in strawberry cv. Chandler under black polythene mulch whereas minimum fruit length of $3.00 \mathrm{~cm}$ and fruit breadth of $2.00 \mathrm{~cm}$ was observed in control. The results are constant with those of previous reports in which plastic mulch treatment recorded maximum fruit size whereas minimum was observed in control (Ghosh and Bera, 2015; Bal and Singh, 2011; Castaneda et al., 2009; Sharma and Khokhar, 2006; Agrawal et al., 2005).

\section{Effect of mulching on fruit weight (g)}

The data pertaining to the weight of fruit is represented in the table 1, which indicated that the fruit weight was highest under black polythene mulch $\left(\mathrm{M}_{8}\right)$ with 125.57 and 128.57 g during 2016 and 2017 respectively with mean value of $127.07 \mathrm{~g}$, subsequently transparent polythene $\left(\mathrm{M}_{7}\right)$ treatment followed with 124.87 and $126.60 \mathrm{~g}$ during the experimental years respectively. The treatment devoid of mulched materials $\left(\mathrm{M}_{0}\right)$ recorded the lowest fruit weight mean value of $109.26 \mathrm{~g}$. This might be due to incorporation of mulches that enhanced the nutrient and moisture availability, thereby, helped in improving the soil conditions for better plant growth, balanced $\mathrm{C}: \mathrm{N}$ ratio and thus increased the production of photosynthates and ultimately enhanced the fruit characters. It maximized fruit weight by proper movement of active food synthates to sink (Singh et al., 2009). Hasan et al., (2005), Moreno and Moreno (2008) observed significantly increased average fruit weight of tomato with plastic mulch and Jenni et al., (2003) observed in lettuce. This may be attributed to larger size of fruits produced by the plants provided with black polythene mulch, due to increased fruit weight and also creation of favourable soil temperature for fruit development. The present results are in line with the findings of Bakshi et al., (2014) in strawberry cv. Chandler, Bal and Singh (2011) in Ber, Singh et al., (2010) in Aonla, Maji and Das (2008) in Guava, Ali and Gaur (2007) in strawberry, Mukherjee et al., (2004) in Ber, Shirgure et al., 2003 in Nagpur mandarin, Gosh and Bauri (2003) in Mango and Singh et al., 2002 in apricot. The improved rind thickness of fruit resulted by mulching treatments may be due to improved internal physiology of developing fruit in terms of better supply of water, nutrients and other compounds vital for their proper growth and development in peach (Yadav et al., 2013).

\section{Effect of mulching on Total Soluble Solids $\left({ }^{\circ} \mathrm{Brix}\right)$}

Treatment difference in terms of TSS content was noticed within an average range of 10.99 to $11.53{ }^{0}$ Brix during the experimental years. The data is presented in Table 2. Black polythene mulch $\left(\mathrm{M}_{8}\right)$ treatment recorded maximum TSS with 11.12 and $11.94{ }^{\circ}$ Brix during 2016 and 2017 respectively, then the forest leaves $\left(\mathrm{M}_{5}\right)$ mulch with values of 10.98 and $11.83{ }^{0}$ Brix in both years of study respectively.

The lowest mean TSS content (10.89 ${ }^{0}$ Brix) was recorded in the treatment no mulch $\left(\mathrm{M}_{0}\right)$. Increase in TSS is due to, increased soil 
temperature $\left(25.37^{\circ} \mathrm{C}\right)$ and maximum nutrient uptake $(198.01 \mathrm{~kg} / \mathrm{ha}$ of Nitrogen and $218.67 \mathrm{~kg} / \mathrm{ha}$ of Potash) under black polythene mulch treatment.

Mulching ensured higher values of soil moisture as a result of reducing water evaporation from the soil surface. The changes occurred in the soil water regime had an obvious effect on fruit quality. Thus, soil maintenance systems by mulching might have a positive influence on the TSS. Bal and Singh (2011) while studying the effect of mulching material in Ber observed that maximum TSS of $12.16 \%$ was recorded with black polyethylene in combination with gramaxone (1 litre/ha).

They also reported that TSS under paddy straw and sarkanda was higher as compared to control. Similar findings were obtained Kim et al., (2008) studied the effect of pre-harvest reflective mulch on growth and fruit quality of plum (Prunus domestica L.) and observed that TSS was higher by $0.3{ }^{\circ}$ Brix in the mulching treatment applied 2 and 3 weeks before harvesting compared to control.

The present observations are consistent with the earlier finding in which black polythene mulch gave better results viz., Bakshi et al., (2014) in Strawberry, Kaur and Kaundal (2009) in Plum, Sharma and Khokhar (2006) in strawberry (Fragaria $\mathrm{x}$ ananassa Duch.) cv. Chandler, Pande et al., (2005) in apple cv. Red Delicious, Gaikwad et al., (2002) in Nagpur mandarin, and Gosh and Bauri (2003) in Mango.

In contrast, Ghosh et al., (2009) reported in sweet orange [Citrus sinensis (L.) Osbeck] $c v$. Mosambi that juice recovery (59.67\%), TSS (9.90 Brix), TSS: acid ratio (46.33), total sugars $(6.05 \%)$, reducing sugars $(3.35 \%)$ were highest in plants treated with dry leaves mulch + basin irrigation at $30 \mathrm{l} /$ plant at 20 days interval. Whereas, acidity (0.28 \%), Vitamin-C $(78.40 \mathrm{mg} / 100 \mathrm{ml})$ was highest in black polythene + basin irrigation at 30 1/Plant at 20 days interval. Manoj et al., (2015) reported maximum TSS in Kinnow under paddy straw mulch. Singh et al., (2010) reported that paddy straw mulch in Aonla cv. NA-7 recorded the maximum TSS of $8.25 \%$ followed by $8.15 \%$ in grass mulch and $8.10 \%$ in maize straw mulch as compared to $7.85 \%$ in control. Kumar et al., (2012) recorded significantly higher TSS in strawberry under transparent polyethylene mulch followed by black polyethylene. They also reported higher TSS under organic mulches.

\section{Effect of mulching on titratable acidity}

In the present investigation, the result obtained on titratable acidity percentage revealed varying degree of response in all the mulch tested. The effective treatment for highest average acidity content $(0.88 \%)$ was reported from black polythene mulch $\left(\mathrm{M}_{8}\right)$ in both years of study, while the treatment deprived of any mulch materials $\left(\mathrm{M}_{0}\right)$ recorded lowest acidity content of 0.86 and $0.88 \%$ during 2016 and 2017 respectively.

Similar results were found by Melgarejo et al., (2012) who reported that organic acids content were slightly higher in plums from trees treated with plastic mulching film. Hassan et al., (2000) studied the effect of different mulches on the yield and quality of strawberry $c v$. Oso Grande and observed minimum acid content in the fruits harvested from plants under black polythene mulch $(1.13 \%)$ and maximum in control $(1.33 \%)$. Pande et al., (2005) found higher titratable acidity of $0.25 \%$ in apple cv. Red Delicious grown under dry grass mulch followed by $0.20 \%$ acid content recorded under black polyethylene and least acid content of $0.19 \%$ was recorded under clean cultivation. 
Table.1 Effect of different mulching materials on fruit yield per tree, fruit size and fruit weight of Khasi Mandarin

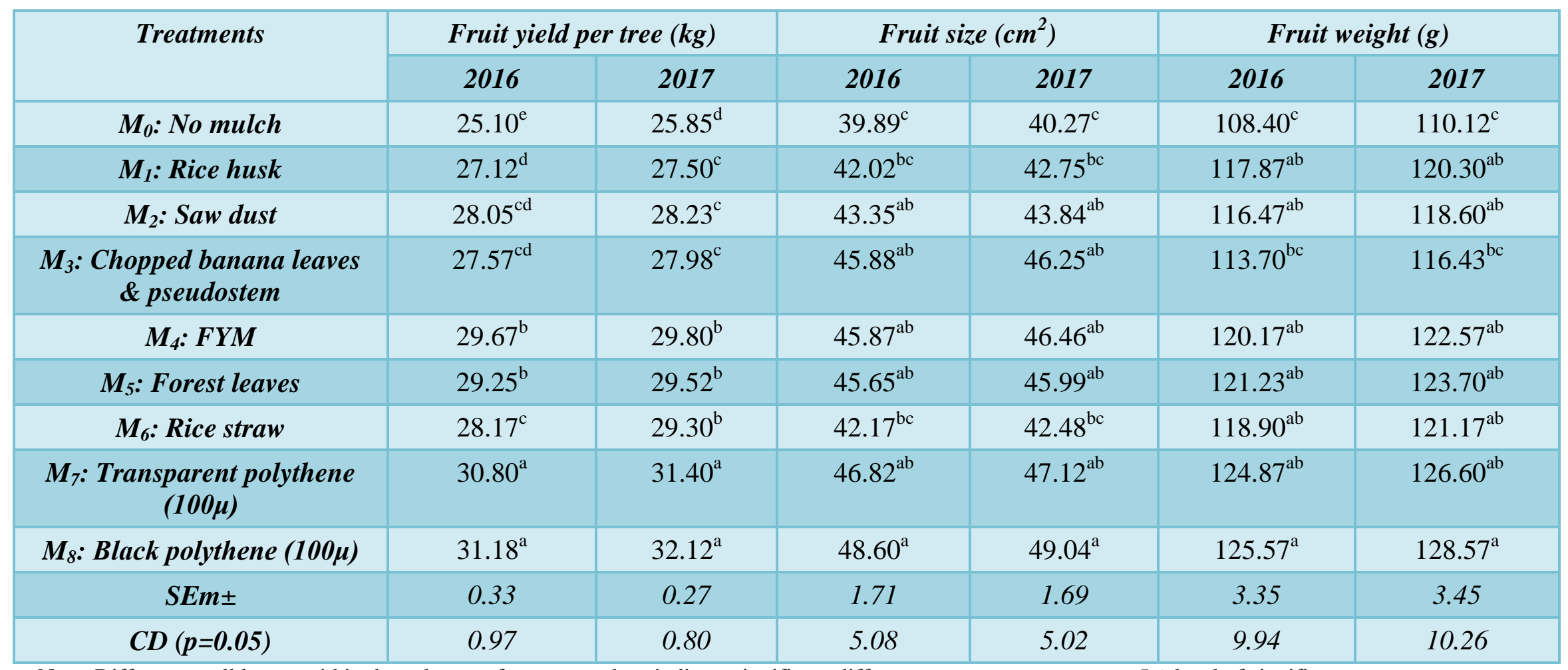

Note: Different small letters within the columns after mean values indicate significant differences among treatments at $5 \%$ level of significance.

Means within columns were separated by Duncan's multiple range test (DMRT). 
Table.2 Effect of different mulching materials on total soluble solids, titratable acidity, firmness and reducing sugar of Khasi Mandarin

\begin{tabular}{|c|c|c|c|c|c|c|c|c|}
\hline \multirow[t]{2}{*}{ Treatments } & \multicolumn{2}{|c|}{$\begin{array}{c}\text { Total soluble solids } \\
\text { (Brix) }\end{array}$} & \multicolumn{2}{|c|}{$\begin{array}{c}\text { Titratable Acidity } \\
(\%)\end{array}$} & \multicolumn{2}{|c|}{ Firmness } & \multicolumn{2}{|c|}{$\begin{array}{c}\text { Reducing sugar } \\
(\%)\end{array}$} \\
\hline & 2016 & 2017 & 2016 & 2017 & 2016 & 2017 & 2016 & 2017 \\
\hline$M_{0}:$ No mulch & $10.47^{\mathrm{c}}$ & $11.32^{\mathrm{c}}$ & $0.23^{\mathrm{c}}$ & $0.26^{c}$ & $3.75^{\mathrm{ab}}$ & $3.67^{\mathrm{ab}}$ & $6.78^{c}$ & $6.68^{\mathrm{b}}$ \\
\hline$M_{1}:$ Rice husk & $10.50^{c}$ & $11.47^{\mathrm{bc}}$ & $0.27^{\mathrm{bc}}$ & $0.30^{\mathrm{bc}}$ & $4.17^{\mathrm{a}}$ & $4.42^{\mathrm{a}}$ & $7.19^{\mathrm{bc}}$ & $7.39^{\mathrm{ab}}$ \\
\hline$M_{2}:$ Saw dust & $10.56^{\mathrm{bc}}$ & $11.56^{\mathrm{ab}}$ & $0.32^{\mathrm{bc}}$ & $0.33^{b c}$ & $3.17^{\mathrm{bc}}$ & $3.08^{\mathrm{bc}}$ & $8.03^{\mathrm{ab}}$ & $8.21^{\mathrm{a}}$ \\
\hline $\begin{array}{c}M_{3}: \text { Chopped banana leaves } \& \\
\text { pseudostem }\end{array}$ & $10.65^{b c}$ & $11.40^{\mathrm{c}}$ & $0.24^{\mathrm{bc}}$ & $0.27^{\mathrm{bc}}$ & $2.75^{\mathrm{cd}}$ & $2.83^{b c}$ & $7.48^{\mathrm{abc}}$ & $7.59^{\mathrm{a}}$ \\
\hline$M_{4}: F Y M$ & $10.66^{\mathrm{bc}}$ & $11.62^{\mathrm{ab}}$ & $0.30^{\mathrm{bc}}$ & $0.33^{b c}$ & $2.50^{\mathrm{cd}}$ & $2.42^{\mathrm{c}}$ & $7.75^{\mathrm{ab}}$ & $7.79^{a}$ \\
\hline$M_{5}:$ Forest leaves & $10.98^{\mathrm{ab}}$ & $11.83^{\mathrm{ab}}$ & $0.43^{\mathrm{a}}$ & $0.44^{\mathrm{a}}$ & $2.67^{\mathrm{cd}}$ & $2.83^{b c}$ & $7.80^{\mathrm{ab}}$ & $8.06^{\mathrm{a}}$ \\
\hline$M_{6}:$ Rice straw & $10.66^{\mathrm{b}}$ & $11.55^{\mathrm{ab}}$ & $0.28^{\mathrm{bc}}$ & $0.31^{\mathrm{bc}}$ & $2.17^{\mathrm{d}}$ & $2.08^{c}$ & $7.39^{\mathrm{bc}}$ & $7.30^{\mathrm{ab}}$ \\
\hline$M_{7:}$ Transparent polythene $(100 \mu)$ & $10.85^{\mathrm{ab}}$ & $11.72^{\mathrm{ab}}$ & $0.33^{\mathrm{b}}$ & $0.36^{\mathrm{b}}$ & $2.50^{\mathrm{cd}}$ & $2.58^{\mathrm{bc}}$ & $7.96^{\mathrm{ab}}$ & $8.18^{\mathrm{a}}$ \\
\hline$M_{8}:$ Black polythene $(100 \mu)$ & $11.12^{\mathrm{a}}$ & $11.94^{\mathrm{a}}$ & $0.43^{\mathrm{a}}$ & $0.45^{\mathrm{a}}$ & $2.67^{\text {cd }}$ & $2.75^{\mathrm{bc}}$ & $8.19^{\mathrm{a}}$ & $8.23^{\mathrm{a}}$ \\
\hline$S E m \pm$ & 0.13 & 0.13 & 0.03 & 0.03 & 0.25 & 0.27 & 0.26 & 0.28 \\
\hline$C D(p=0.05)$ & 0.38 & 0.38 & 0.08 & 0.08 & 0.75 & 0.80 & 0.78 & 0.83 \\
\hline
\end{tabular}

Note: Different small letters within the columns after mean values indicate significant differences among treatments at $5 \%$ level of significance.

Means within columns were separated by Duncan's multiple range test (DMRT). 
However, Kumar et al., (2012) recorded significantly higher fruit acidity in strawberry under transparent polyethylene followed by black polyethylene. The minimum fruit acidity was obtained under control. Bakshi et al., (2014) recorded highest acidity of $0.80 \%$ under control whereas, least acidity of $0.64 \%$ was found under black polythene mulch in strawberry cv. Chandler. Gaikwad et al., (2002) while studying the effect of different mulches on soil moisture, and soil temperature in Nagpur mandarin found nonsignificant effect of different mulching treatments on acidity. Gosh and Bauri (2003) while studying the impact of various mulches in mango found that fruit acidity was not influenced by various mulching treatments.

\section{Effect of mulching on firmness}

The results obtained by Hedonic scale method on the firmness of harvest fruits borne under different mulched treatments have been presented in the table 2. It is apparent from the data that, the fruits harvested from rice husk mulch $\left(\mathrm{M}_{1}\right)$ was firmest with an average value of 4.29, 3.71 and 3.13 was recorded in treatments of no mulch content $\left(\mathrm{M}_{0}\right)$ and saw dust mulch $\left(\mathrm{M}_{2}\right)$ respectively. Fruits harvested from Khasi Mandarin grown under rice straw mulch recorded the softest with mean value of 2.13 .

The firmness and maintenance of structure and function of cell wall, leading to enhanced shelf life and also controlled disintegration of mitochondria and endoplasmic reticulum might be due to effect of mulching since it results in many of the chemical and physical effects that occur during ripening of fruits which are attributed to enzyme action. Softening of fruits during storage is closely associated with an increase in pectin esterase and polygalacturonate activities as reported by Bakshi et al., (2014) in Strawberry. Similar finding by Lang et al., (2001) reported that mulching the plants helps in better uptake of calcium by the apple tree which will be reflected in storage potential of the fruit.

\section{Effect of mulching on reducing sugar}

In the present investigation, the results obtained on reducing sugar percentage revealed varying degree of response in all the mulch tested. It was clear from the results presented in table 2 that black polythene mulch $\left(\mathrm{M}_{8}\right)$ resulted in highest reducing sugar content with values of 8.19 and $8.23 \%$ during 2016 and 2017 respectively. The mulch treatments of saw dust $\left(\mathrm{M}_{2}\right)$ and transparent polythene $\left(\mathrm{M}_{7}\right)$ closely followed with mean values of 8.12 and $8.07 \%$ respectively. The lowest was recorded in treatments without any mulch materials $\left(\mathrm{M}_{0}\right)$ reporting 6.78 and $6.68 \%$ during 2016 and 2017 respectively. The present findings are in line with Patil (2011) who reported highest total sugar (6.21\%) under paddy straw mulch, reducing sugar $(5.38 \%)$ under black polythene mulch and non-reducing sugar (1.22\%) under paddy straw mulch and least under control. Ghosh and Bera (2015) and Mahmoud and Sheren (2014) also recorded the higher sugar acid ratio in plants mulched with black polythene in pomegranate. Similar conclusions that black polythene mulch results in higher reducing sugar have been drawn by others (Sharma and Khokhar, 2006; Pande et al., 2005).

Sugars are important in attaining pleasing fruit flavours through a sugar to acid balance, attractive colour and wholesome texture. Higher reducing sugar content under black polythene mulch might be due to high TSS and greater utilization and assimilation of carbohydrates favoured by better hydrothermal regime of soil and higher absorption of nutrients, conservation of soil moisture, regulated temperature and 
suppression in weed growth. Moisture in the mulched treatments might have helped in better nutrient uptake which was more influenced by the physical conditions of the soil (temperature and moisture) and availability of nutrients in the soil. Mulching also elevates fruit yield and sugar content, which was influenced by environmental conditions at flowering, fruit set and the early stages of fruit development (Singh et al., 2006) in strawberry.

In contrast, Kumar et al., (2012) recorded significantly higher total sugars in strawberry under transparent polyethylene mulching followed by black polyethylene. Das et al., (2010) while studying the effect of soil covers on guava cv. L-49 reported maximum total sugar $(6.53 \%)$, reducing sugar $(3.80 \%)$ and non-reducing sugar $(2.72 \%)$ under paddy straw mulch as compared to other mulches and control.

\section{References}

Agrawal, N., Sharma, H.G., Agrawal, S., Dixit, A. and Dubey, P. 2005. Comparative study of drip irrigation and surface method with and without plastic mulching in mango cv. Dashehari. Haryana Journal of Horticultural Sciences. 34(1-2): 9-11.

Ali, A. and Gaur, G.S. 2007. Effect of mulching on growth, fruit yield and quality of strawberry (Fragaria $\mathrm{x}$ ananassa Duch). Asian Journal of Horticulture. 2(1): 149-151.

Amarine, M.A., Pangborn, R.M. and Roessler, E.B. 1965. Principles of sensory evaluation of food. Academic Press, New York. 602 pp.

AOAC. 2002. Official methods of analysis.12th Edn. Association of Official Agricultural Chemists International, Washington D.C. pp. 112.
Bakshi, P., Bhat, D.J., Wali, V.K., Sharma, A. and Iqbal, M. 2014. Growth, yield and quality of strawberry (Fragaria $\mathrm{x}$ ananassa Duch.) cv. Chandler as influenced by various mulching materials. African Journal of Agricultural Research. 9(7): 701-706.

Bal, J.S. and Singh, S. 2011. Effect of mulching material and herbicides on tree growth, yield and fruit quality of ber. Indian Journal of Horticulture. 68(2): 189-192.

Castaneda, L.M.F., Antunes, L.E.C., Ristow, W.C. and Carpenedo, R.S. 2009. Utilization of different mulching types in strawberry production. Acta Horticulturae. 842: 111-113.

Das, B.C., Maji, S. and Mulieh, S.R. 2010. Response of soil covers on guava cv. L49. Journal of Crop and Weed. 6(2): 1014.

Gaikwad, S.C., Ingle, H.V. and Panchbhai, D.M. 2002. A note on the effect of different types of mulches on growth, yield and quality of Nagpur mandarin. Orissa Journal of Horticulture. 30(1): 137-138.

Ghosh, S.N. and Bera, B. 2015. Effect of mulching on soil moisture, yield and quality of pomegranate. Indian Journal of Soil Conservation. 43: 92-95.

Ghosh, S.N., Dattaray, S.K. and Megu, O. 2009. Effect of mulching and irrigation on fruit yield and quality of sweet orange [Citrus sinensis (L.) Osbeck] cv. Mosambi. International Journal of Agriculture Environment and Biotechnology. 2(1): 42-45.

Gomez, K.H. and Gomez, A.A. 1984. Statistical procedures for Agricultural Research. John Wiley and Sons. New York. 381.

Gosh, S.N. and Bauri, F.K. 2003. Effect of mulching on yield and physiochemical properties of mango fruits cv. 'Himsagar' grown in rainfed laterite 
soils. Orissa Journal of Horticulture. 31(1): 78-81.

Hasan, M.F., Ahmed, B., Rahman, M.A. and Khan, M.M.H. 2005. Environmental effect on growth and yield of tomato. Journal of Biological Sciences. 5(6): 759-767.

Hassan, G.I., Godara, A.K., Kumar, J. and Huchehe, A.D. 2000. Effect of different mulches on yield and quality of Oso Grande strawberry. Indian Journal of Agricultural Sciences. 70: 184-185.

Horticultural Statistics at a Glance. 2018. Department of Agriculture, Cooperation \& Farmers' Welfare Ministry of Agriculture \& Farmers' Welfare Government of India. National Horticulture Board. http://nhb.gov.in/statistics/State Level/201819(1st\%20Adv).pdf

Jenni, S., Dubuc, J.F. and Stewart, K.A. 2003. Plastic mulches and row covers for early and mid season crisphead lettuce produced on organic soils. Canadian Journal of Plant Science. 83(4): 921929.

Kaur, K. and Kaundal, G. 2009. Efficacy of herbicides, mulching and sod cover on control of weeds in plum orchards. Indian Journal of Weed Science. 104: 110-112.

Kher, R., Baba, J.A., Bakshi, P. and Wali, V.K. 2010. Effect of planting time and mulching material on quality of strawberry. Journal of Research SKUAST. 9(1): 54-62.

Kim, E.J., Choi, D.G. and Jin, S.N. 2008. Effect of pre-harvest reflective mulch on growth and fruit quality of plum (Prunus domestica L.). Acta Horticulturae. 772: 323-326.

Kumar, R., Tandon, V. and Mir, M.M. 2012. Impact of different mulching materials on growth, yield and quality of strawberry (Fragaria $\mathrm{x}$ ananassa Duch). Progressive Horticulture. 44(2): 234-
236.

Lang, A., Behboudian, M.H., Kidd, J. and Brown, H. 2001. Mulch enhances apple fruit storage quality. Acta Horticulturae. 557: 433-439.

Mahmoud, I.E.D. and Sheren, E.H. 2014. Improving growth and productivity of pomegranate fruit trees planted on sandy dunes slopes at Baloza District (N. Sinai) using different methods of drip irrigation, organic fertilization and soil mulching. IOSR Journal of Agriculture and Veterinary Science. 7(12): 86-97.

Maji, S. and Das, B.C. 2008. Response of mulching on fruit quality and yield of guava (Psidium guajava L.). Journal of Environment and Ecology. 26(4): 16301631.

Mal, B., Banik, B.C., Ghosh, S.N. and Maity, P.K. 2006. Studies on the effect of mulching in pomegranate cv. Ganesh. Proceedings of National symp. Prod. Util. and Export of Under Utilized Fruits with Commercial Potentialities, held at Bidhan Chandra Krishi Vishwavidyalaya, West Bengal, November 22-24. pp. 163-167.

Manoj, B., Sindhu, S., Preeti, S. and Prince. 2015. Effect of various mulches on growth, yield and quality of kinnow. The Bioscan. 10(3): 1379-1382.

Melgarejo, P., Sanchez, A.C., Hernandez, F., Szumny, A., Martinez, J.J., Legua, P., Martinez, R. and Carbonell-Barrachina, A.A. 2012. Chemical, functional and quality properties of Japanese plum (Prunus salicina Lindl.) as affected by mulching. Scientia Horticulturae. 134: 114-120.

Moreno, M.M. and Moreno, A. 2008. Effect of different biodegradable and polythene mulches on soil properties and production in a tomato crop. Scientia Horticulturae. 116: 256-563.

Mukherjee, S., Paliwal, R. and Pareek, S. 2004. Effect of water regime, mulch and 
kaolin on growth and yield of ber. Journal of Horticulture Science and Biotechnology. 79(6): 91-99.

Pande, K.K., Dimri, D.C. and Kamboj, P. 2005. Effect of various mulches on growth, yield and quality of apple. Indian Journal of Horticulture. 62:145147.

Patil, N. 2011. Response of strawberry (Fragaria $\mathrm{x}$ ananassa Duch.) cv. Chandler to different mulches. M.Sc. thesis submitted to G. B. Pant University of Agriculture and Technology, Pantnagar, Uttrakhand, India.

Patra, R.K., Debnath, S., Das, B.C. and Hasan, M.A. 2004. Effect of mulching on growth and fruit yield of guava cv. Sardar. Orissa Journal of Horticulture. 32(2): 38-42.

Ranganna, G.S. 2008. Handbook of analysis and quality control for fruit and vegetable products. $2^{\text {nd }} E d n$., Tata $M c$ Graw-Hill Publisher, New Delhi-110 002. pp. 162-182.

Sharma, C. and Khokhar, U.U. 2006. Effect of different mulches and herbicides on growth, yield and quality of strawberry (Fragaria $\mathrm{x}$ ananassa Duch.) cv. Chandler. In: Temperate Horticulture: Current Scenario. New India Publishing Agency, New Delhi (India). pp. 313-320.

Sharma, J.C. and Kathiravan, G. 2009. Effect of mulches on soil hydrothermal regimes and growth of plum in mid hill region of Himachal Pradesh. Indian Journal of Horticulture. 66(4): 465-471.
Shirgure, P.S., Sonkar, A.K., Singh, S. and Panighrah, P. 2003. Effect of different mulches on soil moisture conservation, weed reduction, growth and yield of drip irrigated Nagpur mandarin (Citrus reticulata). Indian Journal of Agricultural Sciences. 73(3): 148-152.

Singh, A.K., Singh, S., Rao, V.V.A., Bagle, B.G. and More, T. A. 2010. Efficacy of organic mulches on soil properties, earthworm population, growth and yield of aonla cv. NA7 in semi- arid ecosystem. Indian Journal of Horticulture. 67: 124-128.

Singh, R., Asrey, R. and Kumar, S. 2006. Effect of plastic tunnel and mulching on growth and yield of strawberry. Indian Journal of Horticulture. 63(1): 18-20.

Singh, R., Bhandari, A.R. and Thakur, B.C. 2002. Effect of drip irrigation regimes and plastic mulch on fruit growth and yield of apricot (Prunus armeniaca). Indian Journal of Agricultural Sciences. 72(6): 355-357.

Singh, R., Kumar, S., Nangare, D.D. and Meena, M.S. 2009. Drip irrigation and black polythene mulch influence on growth, yield and water-use efficiency of tomato. African Journal of Agricultural Research. 4(12): 14271430.

Yadav, V., Singh, P.N. and Yadav, P. 2013. Effect of foliar fertilization of boron, zinc and iron on fruit growth and yield of low-chill peach cv. Sharbati. International Journal of Science and Research. 3: 1-6.

\section{How to cite this article:}

Alongba Jamir, Manoj Dutta and Sentirenla Jamir. 2020. Influence of Organic and Inorganic Mulches on Yield and its Attributes of Khasi Mandarin (Citrus reticulata Blanco) in Foothill Region of Nagaland. Int.J.Curr.Microbiol.App.Sci. 9(10): 1994-2004. doi: https://doi.org/10.20546/ijcmas.2020.910.243 